Ethiopian Journal of Environmental Studies \& Management 7(4): 339 - 3522014

ISSN:1998-0507

doi: http://dx.doi.org/10.4314/ejesm.v7i4.1

Submitted: July 20, 2013

Accepted: June 03, 2014

\title{
DEMAND ASSESSMENT FOR SUSTAINABILITY IN URBAN TOLL ROADS: PRACTICALITIES FROM THE CONTINGENT VALUATION METHOD
}

\author{
OTEGBULU, A.C. AND *FAMUYIWA, F. \\ Department of Estate Management, Faculty of Environmental-Sciences, University of Lagos, \\ Lagos, Nigeria.
}

\begin{abstract}
The paper aims at assessing effective demand of toll roads in the context of user demand and willingness-to-pay (WTP). The specific objectives are to establish mitigation costs associated with existing roads, to find out users' involvement in project planning and what an average user will be willing to pay for improved road conditions. Using a sample of 500 observations, with a response of 356 (71.2\%), effective demand for toll roads and willingness-to-pay along Lekki-Ajah corridor (Lekki toll road concession) in Lagos was investigated. Data was analyzed using descriptive statistics, and the discounted cash flow technique to ascertain project viability. The result of the analysis shows that majority of the respondents and commuters complained of not being consulted at the planning stage of the project, which affected the viability and willingness to pay (WTP) figures. Also, commuters suffer consequential damages and delay in travel time due to poor road conditions. Stakeholder consultation in infrastructure planning and provision is rarely undertaken in Nigeria. This paper is therefore designed to expose the implication of this practice to successful Public-Private-Partnership.
\end{abstract}

Key Words: Demand, Lagos, PPP, Toll-roads, Willingness-to-pay

\section{Introduction}

Road network developments are costly. In most parts of the developing world, they are either inadequate or in poor conditions. This leads to an array of urban problems resulting in poor sustainability implications particularly in socio-economic dimensions. A major and integral part of sustainable development is efficient provision of environmentally sound infrastructure such as transportation and communication, power, water supply and sanitation.

Traditionally, infrastructure has been within the exclusive province of the public sector because of its natural monopolistic features. With few exceptions, the public sector has been an inefficient provider of infrastructure (Panayoutou, 1998). Weak infrastructure linkages in Nigeria today, subject the nation to low competitiveness in

*Corresponding Author: Famuyiwa, F.

Email ffamuywa@unilag.edu.ng global markets. Bridging the infrastructure gap is therefore an important element of promoting both national and regional integration. Infrastructure deficiencies constrain private investment productivity in most developing cities like Lagos, as most firms must invest a good proportion of their capital on alternatively providing infrastructure services. Traffic congestion for example impedes the movement of goods and services and thus reduces the economics of agglomeration of urban markets (Otegbulu, 2010). The problems and difficulties associated with transportation within towns and cities are readily apparent, and feature daily in the life of urban dwellers (Brutton, 1975). Investments in urban transportation are increasingly being embarked upon in urban environments, in order to ameliorate problems of congestion. But in Lagos and 
other parts of Nigeria, the problem of road infrastructure is quite daunting.

Roads need to be regularly maintained even after completion of development, because as they become more utilized, the pressure on them causes gradual deterioration, and the costs of operating vehicles begin to increase. The neglect of road maintenance often continues because it is the vehicle operators that pay these costs and pass them on to commuters - where such is possible. Most often, road users are slow to see the link between road conditions and prices of goods and transport services (World Bank, 1998).

All tiers of government in Nigeria are beginning to realize the difficulty in funding infrastructural projects through budgetary allocation. New approaches to addressing these problems include collaboration among an increasing number of stakeholders. PublicPrivate- Partnership (PPP) is one of the most promising forms of such collaborations (Darko, 2003). It implies that the roads or other infrastructure constructed under such arrangement would have to be tolled so that private investors are ultimately able to recoup their capital. It is therefore critical to the project success that the demand for and viability of a project is established. In addition, end users who will pay user charges in form of tolls must be involved in the planning process of such structures. Government and private investors cannot build partnerships alone. Political and social acceptance of private sector involvement is essential.

According to Mabogunje (1993), it is important that residents are fully informed of all proposed development infrastructure in a city. It is necessary that they are given an opportunity to have an input in the decision making process, especially when this involves financial obligations for which they will eventually be responsible - either through some form of taxation or user charges.

Road infrastructure is an environmental good and very few environmental goods and services have markets. Hence the need to resort to environmental valuation techniques, one of which is the contingent valuation model (CVM). The CVM entails establishing the maximum willingness-to-pay (WTP,) of potential users, for improvement(s) in an environmental amenity or the minimum willingness-to-accept-compensation (WTAC) to forgo such an improvement.

It is also described as the 'stated preference method'. WTP is a measure of an individual or a society's preference for a particular good or service. The higher the preference, the higher the willingness to pay (Hanley and Splash 1999; Garrod and Willis 2001).

Contingent valuation models are based on hypothetical market situations which elicit the prices of those goods and services which cannot be priced in the market place (Callan and Thomas, 1996; Field and Field, 2002). Toll roads are not common features in Nigerian cities. The few toll roads that existed along highways were suspended over a decade ago. Even then, tariff settings were not based on economic studies. Nigerians are not used to the concept of tolls on urban roads and may resist such schemes in the absence of alternative routes. A practical case in point is the Lekki-Epe expressway which evoked protests from the users, over toll payments. This is a probable source of political and litigation risk, and also a motivation for this study.

For the purpose of clarity, a toll is a charge levied for road use. Broadly speaking, vehicles are charged for road use per trip so that only cost justified trips are undertaken (Newberry 1990, Burris and Pendyala 2002, Runhaar 2001). In the absence of pricing, public roads are available to all on a first come first serve basis, road services 
beingrationed only by congestion. Individuals, whose times are least valuable to them, stay on the roads, while those who cannot afford to waste time in traffic move their works or homes to closer areas (Newberry 1990, Burris and Pandyala 2002, Runhar 2001). The motive behind the call for efficient pricing in transport studies is the presence of inefficiencies in transport markets.

This paper aims at assessing effective demand for toll roads using the willingness to pay method. The outcome will also help in addressing the problem of user resistance and tariff settings. Ultimately, the aim of this study will be achieved through the following objectives;

- To establish the mitigation costs associated with the existing road in the study area.

- To find out if users were involved during the planning of the road project.

- To determine the impact of road conditions on the travel time by users.

- To determine what an average user will be willing to pay as toll if the road conditions are improved.

Urban transport projects often experience the problem of improper costing/cost benefit analysis. According to Flyvbjerg, Holm and Bhut (2004) cost escalation is a pervasive phenomenon in transport infrastructure projects across project types, geographic locations and historical periods. The authors are also of the view that cost escalations are more prevalent in developing countries than in the developed world.

The main factors affecting the extent of toll impacts include; total trip costs; availability of alternative routes; and values of time used in the various modeling stages. People will patronize toll roads if it provides alternatives to congested roads and hence reduce travel time and problems associated with road congestions. In economic evaluations of road schemes, it is important to estimate the benefits from the roads as well as the net revenue from maximizing tolls (World Bank, 2000). Excess tariff could affect the viability of a toll road while very low tariff could lead to traffic congestion and defeat the benefit of the toll road. It is therefore more appropriate to start with a moderate toll charge and adjust progressively.

Market demand can be measured in terms of actual or expected traffic, and willingness of users to pay tolls. Each measure is critical in demonstrating a revenue stream of sufficient magnitude and predictability to obtain financing (Fisher and Barber 1996). Traffic projections for improvement to existing roads have moderate predictability, while new roads have the least predictable traffic, since speculative judgments must be made about its ability to draw traffic from existing alternatives, and to generate new traffic. Users' willingness to pay tolls is mostly a function of their income, the value they assign to time savings, other toll road benefits and the cost and quality of competitive alternatives (Fisher and Barber 1996). In most toll road projects there is often, or there should be an alternative route which commuters can use.

The government's basic policy has been to dissociate toll settings from the financial needs of concessionaires. Tolls should be set according to traffic allocation criteria, with special transfer and subsidization being used as incentives to even out the financial returns of projects. This policy makes economic sense, since tolls are set exclusively to cover investments, maintenance, and operating costs. High tolls will result in low traffic while low tolls will result in high traffic volumes and congested conditions (Lorenzen et al., 2000). Both situations will defeat the essence of toll road projects. Most often, road users' willingness and ability to pay may not be able to cover the cost of road construction, 
operation and maintenance hence the need for subsidies - where the project is of socioeconomic relevance to the public. Generally, economists and organizations such as the World Bank recommend the use of present value approach as it has the advantage of reducing the importance of accurate traffic forecasts in assessing the demand risks inherent in concession contracts. When the present value of revenue is used as the valuation criterion, bidders in effect disclose the revenue they require to meet their targeted investment return. This has the advantage of discouraging artificial low bid and minimizing the scope for renegotiation during the life of the contract. It also has a second advantage of increased flexibility in contractual arrangement because of the relative ease of computing compensation for termination of the concession (Fisher and Babbar 1996 Lorenzen et al 2000). According to Engel, Fisher and Galetovic (1997) the basic principle underlying the least present value revenue auctions is that the franchise holder should not make losses when the long - run demand for the highway is significant to pay all costs. Revenues are the same, even with different demand realizations, so the risk borne by the franchise holder is less than under fixed term franchises. For this reason, the franchise holder requires a small risk premium for users to pay less on average. Like any other form of project or development, there are risks associated with toll road developments. Solid public support for a project must be evidenced during the development phase to protect the project against political backlash and change of law in subsequent phases of the project due to changes in governments or their policies. Situations like this are not uncommon in Nigeria. Some of the risks include the following; pre-construction, construction, traffic and revenue, currency, political and financial (Fisher and Barber 1996, Bozzo 1997).

\section{Study Area}

Lagos State is the $17^{\text {th }}$ largest urban agglomeration in the world. (Bloom and Khana, 2007, United Nations Development Programme -UNDP, 2006).

According to the National Census Board of Nigeria (2006), the population of Lagos is about 9,013,534 people. This projection implies that Lagos is a mega city. The cosmopolitan status it holds today has been acquired over the years. Until the early 1990s it was the administrative capital of Nigeria. The population undoubtedly causes a strain on available infrastructure, of which roads are no exception. The Lekki corridor in Eti Osa local government area of the state, which is very close to the Atlantic ocean is very much representative of the description above. The project under study is the Lekki toll road concession, which stretches from Victoria Island Lagos to Epe in Metropolitan Lagos. The road project is being handled by Lekki concession company (LCC) which involves the Lagos State Government as the public partner and a consortium of private companies under the umbrella of ARMAssets and Resources Management Ltd. The road covers a distance of $49.4 \mathrm{Km}$ and estimated to cost $\$ 300$ milion (USD) or $\$ 45$ billion (Nigerian Naira). The concession period is expected to cover a period of 30 years (Adedeji, 2009). 


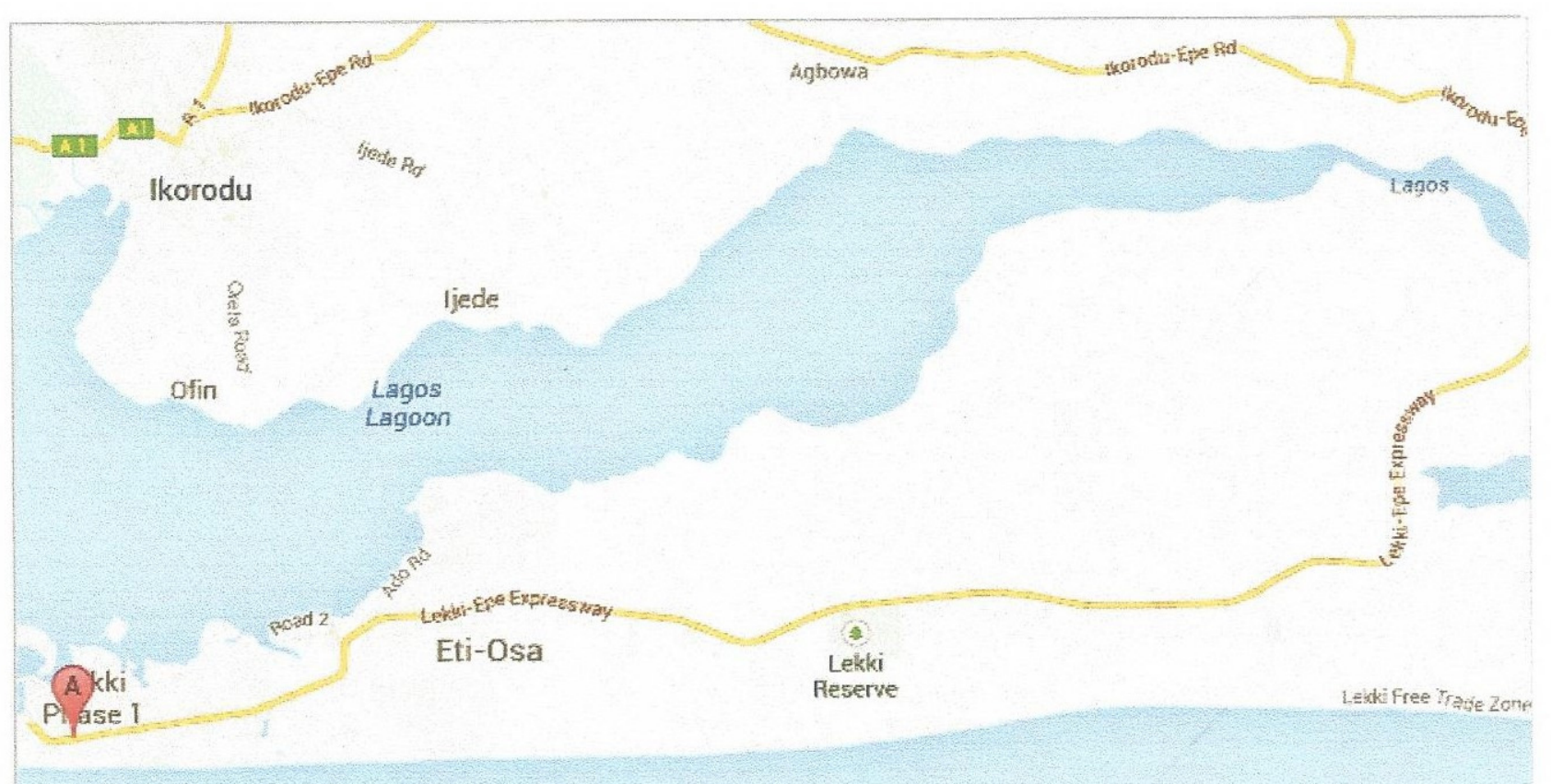

Figure 1: Part of Lagos Metropolis Showing part of study area

\section{Materials and Methods}

Questionnaires were distributed (using random sampling technique) in residential estates and offices along the Lekki corridor to 500 likely users including commercial drivers of the road out of which 356 were retrieved $(71.2 \%$ response). These respondents represent those that ply the route frequently. Questions were asked to obtain information from respondents on income levels, opinions about the on-going road upgrade, difficulties encountered with the road prior to upgrade, traffic delays, average expenditure due to bad road conditions (mitigation costs), participation in planning of the road, and willingness to pay tolls for improved road conditions and capacity. Quantitative analysis was carried out with descriptive statistics. Efforts were made to avoid bias through the use of face to face interviews and easy to understand questionnaires among others.

To determine the traffic volume, field assistants were strategically stationed in various locations at different hours of the day, for many days, to take count of the volume of traffic. Based on this, a traffic volume of 3,700 vehicles per day was estimated. The route serves both intra-city and intercity traffic.

Data from the projected income was used to prepare a discounted cash flow in determining the gross present value as a benchmark for the determination of maximum capital outlay for the project. It is assumed that if the contract sum goes beyond the net present value, the project will not break-even within the concession period.

In the study, it was assumed that the number of vehicles will increase annually; cars by $5 \%$, Buses by $2 \%$ and trucks Nil. Provision is also made for $20 \%$ increase in tariff every 5 years. This information is based on the observed changes in the flow of traffic over time, and projected economic activities along the route. This is based on the record of traffic flow over the years as provided by the Lagos State traffic management authority.

\section{Respondents Characteristics}

From the field survey response; 82.03\% reside along the project route while $17.97 \%$ will feel the impact of the project on a more frequent basis. $4.4 \%$ of the respondents are under $20 \mathrm{yrs}, 51.6 \%$ are between $20-30 \mathrm{yrs}$, $32.7 \%$ are between $31-40 y e a r s, 6.8 \%$ are 
between 41 - 50 years while $4.4 \%$ are between $51-60$ years. Most of the respondents are also well educated as $5.6 \%$ attended primary school, $3.7 \%$ received a secondary school education, $21.9 \%$ went to a polytechnic for tertiary education, $48.3 \%$ completed a basic university education, and $18 \%$ and $2.5 \%$ possess masters and doctorate degree respectively.

Table 1: Problems faced as a result of bad roads

\begin{tabular}{lcc}
\hline Nature of problem & Frequency & Percentage $(\%)$ \\
\hline Delay in Vehicular movement & 190 & $54.8 \%$ \\
Damage to Vehicle & 108 & $31.1 \%$ \\
Increased Transportation Cost & 36 & $10.4 \%$ \\
Robbery & 11 & $3.2 \%$ \\
Air Pollution & 2 & $0.6 \%$ \\
Total & 347 & $100.0 \%$ \\
\hline
\end{tabular}

Table 2: Daily amount of Delay Experienced due to Bad State of the Road

\begin{tabular}{lcc}
\hline Category & Frequency & Percentage (\%) \\
\hline $5-10$ minutes & 29 & $8.7 \%$ \\
$11-12$ minutes & 38 & $11.4 \%$ \\
$21-30$ minutes & 11 & $3.3 \%$ \\
$31-40$ minutes & 21 & $6.3 \%$ \\
$41-50$ minutes & 30 & $9.0 \%$ \\
$51-60$ minutes & 34 & $10.2 \%$ \\
Above 60 minutes & 171 & $51.2 \%$ \\
Total & 334 & 100.0 \\
\hline
\end{tabular}

Table 1 above shows the nature of difficulty experienced by road users prior to the on-going improvement. The major problems experienced by road users were found to be 'damage to vehicles' and 'delay in travel time'. The seriousness of damage experienced by commuters could influence their WTP for improved road conditions. Table 2 shows that $51.2 \%$ of the respondents experienced 60- minute delays due to bad state of the road, $11.4 \%$ of the respondents experienced 11-12minutes delay. The least amount of delay experienced was $21-30$ minutes (faced by $3.3 \%$ of respondents). Lagos residents, under normal circumstances, will be willing to pay tolls for less congested routes. From the literature, users WTP tolls are usually a function of their income, the value they assign to time saving and other toll benefits.

Figure 1 shows that $51.9 \%$ of the respondents incur an average cost of $\mathrm{N} 11,000.00$ on their vehicles monthly. Due to bad roads, $22.8 \%$ spend an average of N15,500.00. $14.7 \%$ of the respondents spend an average of $\mathrm{N} 25,500.00$, and $10.5 \%$ of the respondents spend $\mathrm{N} 30,000.00$ on their vehicles monthly due to bad road conditions. Majority of the respondents spent an average of N11,000.00 on their vehicles monthly due to bad road conditions of the Lekki-Epe expressway prior to upgrading. Users' averting behavior is a likely indication of their WTP for improved road conditions. Figure 2 shows that more than $94 \%$ of the respondents are aware of ongoing upgrading of the Lekki-Epe expressway. 


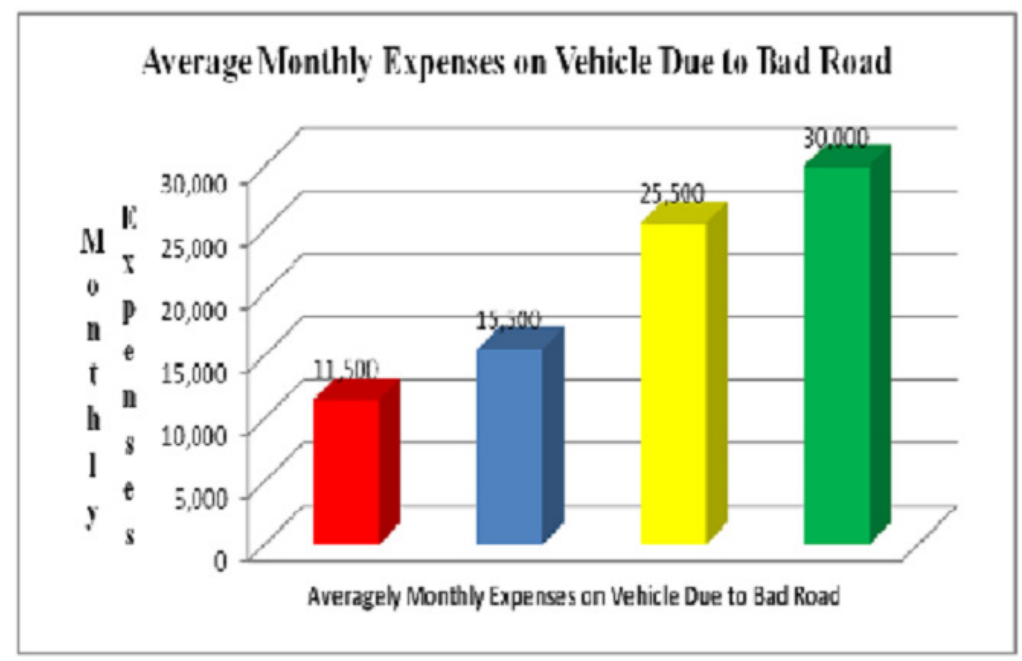

Figure 1. Average monthly expense on vehicle due to bad road conditions

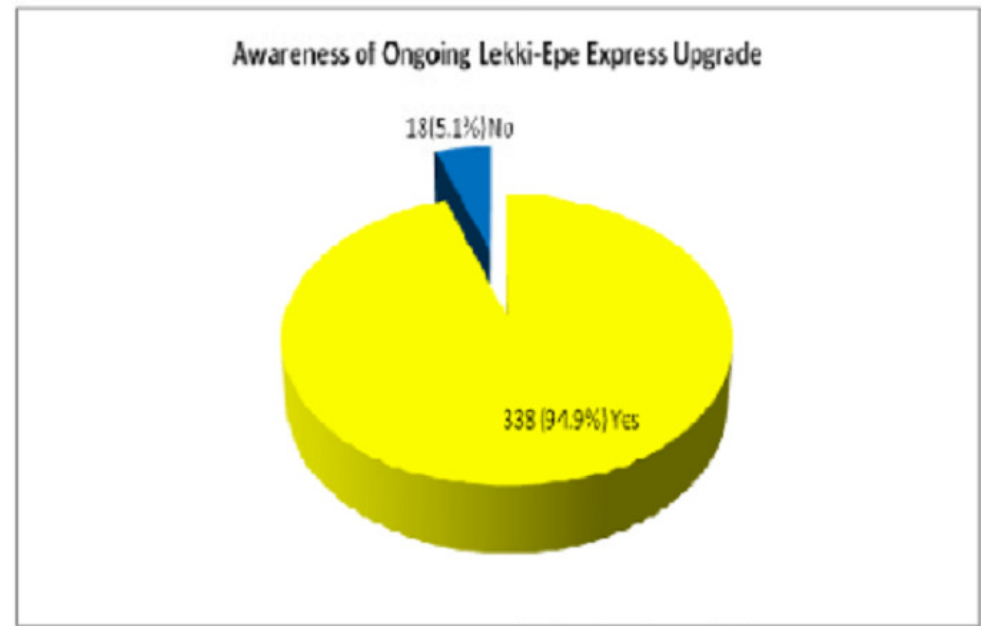

Figure 2. Awareness of ongoing Lekki-Epe Expressway Upgrade

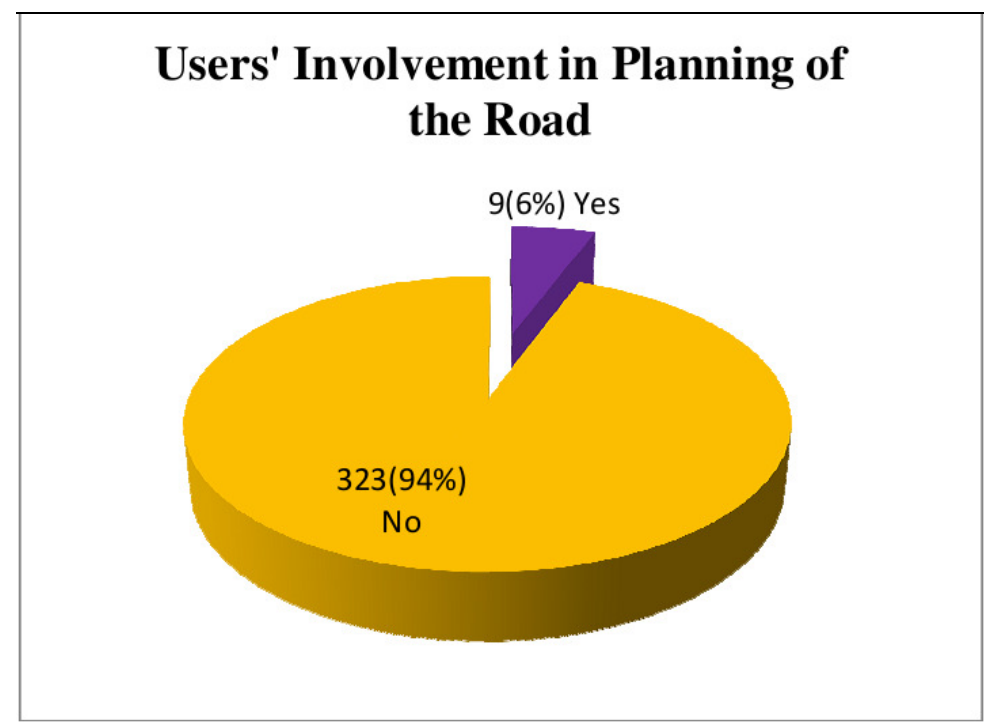

Figure 3: User involvement in the planning process of the road expansion 


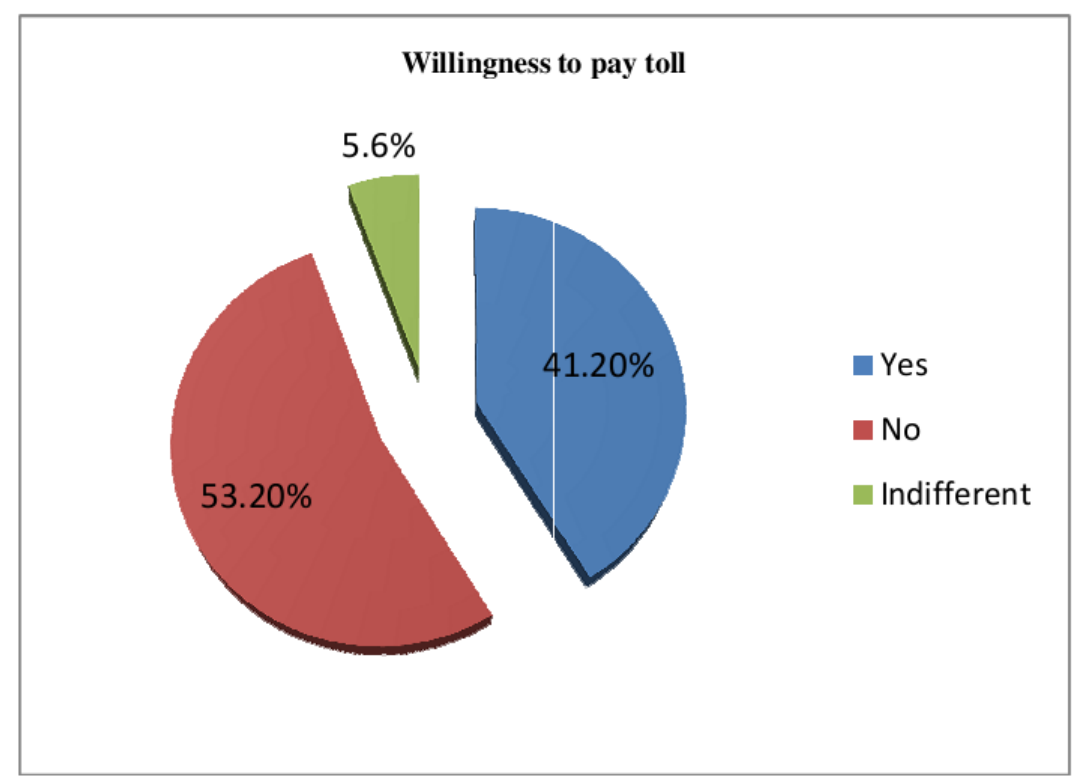

Figure 4: Willingness to pay Tolls

Figure 3 shows that more than $94 \%$ of the users were not involved during the planning phase of the road expansion. This implies that the road users were not consulted as to their specific needs regarding the road improvement in terms of the road conditions and capacity, and also on their willingness to pay (WTP) for the improvement. The process therefore cannot be regarded as democratic.

Figure 4 shows that $(53.2 \%)$ of the respondents are not willing to pay tolls, $(41.2 \%)$ of the respondents are willing to pay tolls while $(5.6 \%)$ are indifferent. Their grouse centers mainly on non-consultation in the planning process. This is a sign of poor urban governance. According to Mabogunje (1993) and Darko (2003), end users who will pay user charges in form of tolls must be involved in the planning. Government and private investors cannot build partnerships alone as political and social acceptance of private sector involvement is essential.

Table 3 above shows that majority of the respondents $(72.6 \%)$ are willing to pay toll between $\mathrm{N} 50$ - N100 for cars, $51.7 \%$ for buses and $40.5 \%$ for lorries/trucks. Majority of the respondents want to pay low tolls most likely because they were not consulted during project planning.

This stresses the importance of user or stakeholder involvement in project planning particularly in cases where user charges will be required. If users are convinced on the desirability of the project, their WTP would likely have been higher.

Table 4 shows the amount respondents are willing to pay (toll) for cars, buses and trucks/lorries. The minimum amount the respondents are willing to pay for cars, buses and trucks/lorries is N50.00. The mean amount the respondents are willing to pay for car is N97.00, the mean amount the respondents are willing to pay for buses is N119.00 while the mean amount the respondents are willing to pay for trucks/lorries is N147.00. The trucks/lorries have the highest standard deviation of N61.00, followed by buses with a standard deviation of N49.00 while cars category possesses the lowest standard deviation of N39.00. The dispersion among the vehicle figures shows that WTP for car has the highest reliability figure with the lowest standard deviation value. The implication of this is that buses and trucks/lorries would 
have to pay a little more. This is so as their standard deviation is a little bit far from the mean WTP. The result of the table above will be used for tariff setting. It should also be noted that heavy vehicles cause more damage to roads than smaller vehicles do.

Table 5 shows the mean amount respondents are willing to pay, mean annual income of the respondents and the mean amount delay attributed to bad state of the road. Respondents are willing to pay an average of N120.00 for toll in Lekki-Epe area, the average annual income of road users and residence of Lekki-Epe area is $\mathrm{N} 2,333,300.00$ and average delay attributed to bad state of the road is roughly 48 minutes prior to upgrade of Lekki-Epe expressway. Value attached to travel time and income has influence on WTP.

Table 3: Willingness to Pay (toll) on Cars, buses and Lorries

\begin{tabular}{lcccccc}
\hline & \multicolumn{2}{c}{ Cars } & \multicolumn{2}{c}{ Buses } & \multicolumn{2}{c}{ Trucks/lorries } \\
\hline Category & Frequency & $\begin{array}{c}\text { Percentage } \\
\%\end{array}$ & Frequency & $\begin{array}{c}\text { Percentage } \\
\%\end{array}$ & $\begin{array}{c}\text { Frequency } \\
\text { Percentage } \\
\%\end{array}$ \\
\hline N50-N100 & 114 & 72.6 & 45 & 51.7 & 30 & 40.5 \\
N101-N150 & 19 & 12.1 & 16 & 18.4 & 4 & 5.4 \\
N151-N200 & 20 & 12.7 & 17 & 19.5 & 2 & 2.7 \\
Above N200 & 4 & 2.5 & 9 & 10.3 & 38 & 51.4 \\
Total & 157 & 100.0 & 87 & 100.0 & 74 & 100.0 \\
\hline
\end{tabular}

Table 4: WTP on Cars, Buses and Trucks/Lorries

\begin{tabular}{llll}
\hline Category & Minimum & Mean & S.D \\
\hline Cars & N50.00 & N97.00 & N39.00 \\
Buses & N50.00 & N119.00 & N49.00 \\
Trucks/Lorries & N50.00 & N147.00 & N61.00 \\
\hline
\end{tabular}

Table 5: Mean Willingness to Pay (WTP), Annual income and time delays.

Willingness to pay

Mean Value

Annual Income

Average Delay attributed to bad state of the road

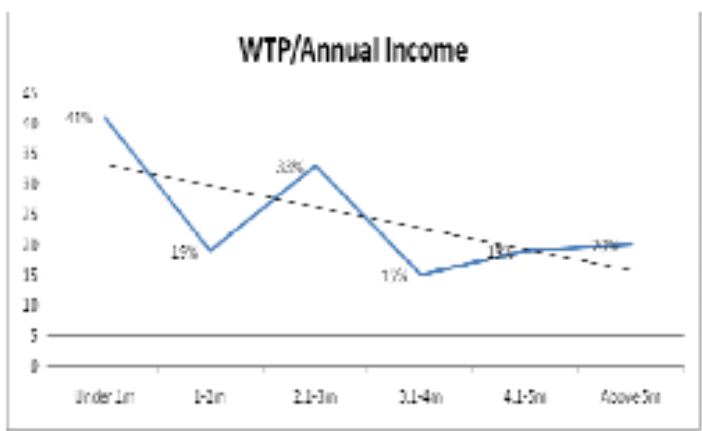

Figure 5: WTP/Annual Income

Figure 5 shows a chart of users' willingness to pay tolls and annual income
N121.66

$\mathrm{N} 2,333,300.00$

48.046minutes

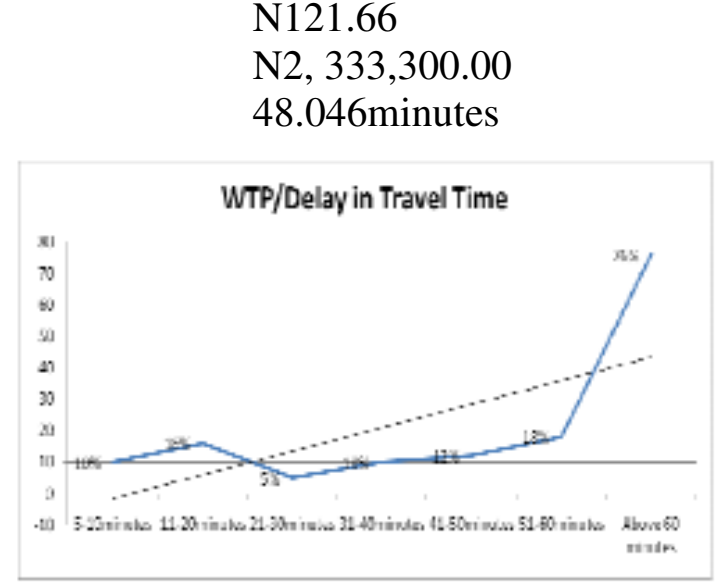

Figure 6: WTP/Delay in Travel Time levels. The vertical axis represents the Willingness to Pay (WTP) values, and the 
horizontal axis represents income levels. This curve shows that there is a fairly negative relationship between annual income levels and willingness to pay. The line shows that majority of the respondents that are willing to pay tolls earn below N1 million annually. This shows that monthly incomes account for high variations in respondents' willingness to pay, but also, there are some other factors that contribute to WTP. From Figure 5, it can be seen that the curve slopes downwards from the range of below N1million earning capacity. However, there is a gradual upward movement corresponding with the range of higher incomes (i.e. incomes higher that $\mathrm{N}$ 1million). This irregular curve can be expected, as the percentage of the respondents that earn between N3.1-4million and above N5million depicts the lowest point of the curve. This invariably affects the trend and movement of the curve. This confirms the correlation between income and WTP.

Figure 6 shows the trend of the respondents' willingness to pay tolls due to delays attributed to bad road conditions. This shows that there is a strong positive relationship between the time attributed to delays from bad road conditions, and willingness to pay tolls. Majority of the respondents that attributed spending more time due to bad roads are willing to pay.
Looking at this graph, it shows that those who experience delays within the range of 60 minutes and 51-60 minutes due to bad road conditions fall within the category of $94 \%$ of the respondents that are willing to pay tolls.

\section{Tariff Settings}

Based on the findings from the willingness to pay survey and in consideration of the mean WTP and standard deviations toll rates are projected for different categories of vehicles that ply the route.

Cars: $\quad \$ 50.00$

Buses: $\quad \$ 100.00$

Trucks and Lorries: $\$ 150.00$

From observation, most vehicles except trucks will use the route twice a day (return journeys inclusive) which implies paying tolls between twice and six times a day. As earlier mentioned the road serves both inter city and intra - city vehicular movements.

Therefore a frequency of thrice a day for cars is adopted (from three toll collection points). This translates to $\$ 150.00 /$ day for cars, and six times a day for buses as most of them are commercial and once a day for trucks and Lorries which are mainly inter - city vehicles.

Traffic volume based on field observation is estimated at 37,000 vehicles per day.

Table 6: Apportionment of traffic volume by vehicle type

\begin{tabular}{lll}
\hline Vehicle type & percentage of traffic volume & no of vehicles \\
\hline Cars & $75 \%$ & 27,750 \\
Buses & $23 \%$ & 8,510 \\
Truck/Lorries & $2 \%$ & 740 \\
\hline Total: & & 37,000
\end{tabular}

Table 7: Projected Revenue

\begin{tabular}{llll}
\hline Vehicle Type & Volume & Toll Rate $(\mathrm{N})$ & Amount $(\mathrm{N})$ \\
\hline Cars & 27,750 & 60 & $1,387,500$ \\
Buses & 8,510 & 100 & 851,000 \\
Trucks/Lorries & 740 & 150 & 110,000 \\
\hline
\end{tabular}

Total daily revenue for the first year $2,348,500$ 
Gross annual revenue: $2,348,500 \times 365=\$ 857,202,500$

Expenses and maintenance cost is assumed at $30 \%$ of the gross revenue.

Net Revenue $=$ 600,041,750

We also assume a $20 \%$ increase in toll rate every 5 years and a $5 \%$ yearly increase in volume of cars and a $2 \%$ yearly increase in volume of buses which give us the following cash flow;

Table 8: Discounted Cashflow

\begin{tabular}{llll}
\hline Years & Net income & $\begin{array}{l}\text { Discount rate } \\
\text { @ } 12 \%\end{array}$ & $\begin{array}{l}\text { Present Value in } \\
\text { Nigerian naira }(\mathrm{N})\end{array}$ \\
1 & $600,297,250$ & 0.8928 & $535,945,385$ \\
2 & $622,359,675$ & 0.7972 & $496,145,133$ \\
3 & $645,380,225$ & 0.7118 & $459,381,644$ \\
4 & $669,435,550$ & 0.6355 & $425,426,292$ \\
5 & $694,551,200$ & 0.5674 & $394,088,351$ \\
6 & $864,949,260$ & 0.5063 & $437,923,810$ \\
7 & $897,510,180$ & 0.4523 & $405,943,854$ \\
8 & $932,171,310$ & 0.4039 & $376,503,992$ \\
9 & $968,074,170$ & 0.3606 & $349,087,546$ \\
10 & $1,005,586,680$ & 0.3219 & $323,698,352$ \\
11 & $1,253,760,984$ & 0.2875 & $360,456,283$ \\
12 & $1,302,933,492$ & 0.2567 & $334,463,027$ \\
13 & $1,354,331,916$ & 0.2292 & $310,412,875$ \\
14 & $1,408,066,632$ & 0.2046 & $288,090,433$ \\
15 & $1,464,266,412$ & 0.1827 & $267,521,473$ \\
16 & $1,819,355,713$ & 0.1631 & $296,736,917$ \\
17 & $1,892,723,560$ & 0.1456 & $275,580,550$ \\
18 & $1,969,497,222$ & 0.13 & $256,034,639$ \\
19 & $2,049,808,537$ & 0.1161 & $237,982,771$ \\
20 & $2,133,789,343$ & 0.1037 & $221,273,955$ \\
21 & $2,660,938,476$ & 0.0926 & $246,402,903$ \\
22 & $2,771,046,712$ & 0.0826 & $228,888,458$ \\
23 & $2,886,260,349$ & 0.0738 & $213,006,014$ \\
24 & $3,006,816,235$ & 0.0659 & $198,149,190$ \\
25 & $3,133,030,169$ & 0.0588 & $184,222,174$ \\
26 & $3,902,839,150$ & 0.0525 & $204,899,055$ \\
27 & $4,067,993,583$ & 0.0469 & $190,788,899$ \\
28 & $4,240,849,042$ & 0.0419 & $177,691,575$ \\
29 & $4,421,876,924$ & 0.0374 & $165,378,197$ \\
30 & $4,611,359,812$ & 0.0334 & $154,019,418$ \\
& Gross Present Value & $9,016,143,166$ \\
\hline & & & \\
\hline
\end{tabular}

The gross development value is in the sum of N9, 016,143,166 (60,107,621 US dollars) the implication of this is that any contract sum above this figure will be unviable.

\section{Discussions}

This paper looked at discussions on effective demand of toll roads and also obtained data to determine if the findings from the respondents satisfy theoretical validity. From the findings, users were not consulted during the planning of the road expansion/upgrading. There had been 
protests from some communities along the Lekki-Epe corridor (as the road is popularly known) against the installation of toll plazas on the route. Inspite of the difficulties encountered by road users on the route, it is a little surprising therefore, that majority $(53.2 \%)$ of them are not willing to pay tolls. It is the opinion of the authors that if the users were consulted and carried along at the planning stage those willing to pay might most probably been in the majority. There is the likelihood of litigation risk at the end of the project. According to Adedeji (2009) the project cost is in the sum of 300 million USD (45 Billion Naira) which translates to $\$ 6,000,000.00$ per kilometer. This is much higher than the national average cost for road construction. Fisher and Barber (1996) explain that the rehabilitation and expansion of existing two-lane roads into four-lane highways was estimated at $\$ 2$ million per kilometer. Considering that labour cost is very low in Nigeria and that most of the construction materials are locally sourced, the new road project is very expensive. In addition, the award of contract appears not to be competitive. If the contract sum was professionally and competitively awarded, the project would be viable and the costs much lower. Top - bottom or command approach to project planning is undemocratic but still in vogue in project provision in Nigeria. Based on the contract sum of 300million U.S dollars as stated in Adedeji (2009), the project will not break-even based on the net present value of N9,016,143,166 $(60,107,621$ US dollars) as indicated in table 13. The discussion with road consultants revealed that the improvement and expansion of the road by four lanes will be between $\mathrm{N} 100,000,000$ and $\mathrm{N} 120,000,000$ per kilometer. On the basis of this, the road project should cost N6,000,000 ( 40 million U.S Dollars) using the rate of N120,000,000 per kilometer.
Traffic volume along the route is estimated at 37,000 vehicles a day because most users will pass through the route at three toll locations on one way which will become six times for a return journey. It is estimated that buses will constitute $23 \%$, trucks $2 \%$ and cars $75 \%$.

Result from the studies also showed that consumers experience delay in travel time and suffer other costs like car damage and high fuel consumption rates due to poor road conditions. However, non consultation of users affected respondents WTP which indicates that Public Participation is key to effective infrastructure provision. The result of the analysis further shows a correlation between WTP and Income/delay in travel time

\section{Recommendation and Conclusion}

From experience stakeholder consultation and comprehensive studies for infrastructure provision is not the norm in Nigeria, and this is the genesis of many white elephant projects in the country. It is therefore recommended that such studies should be carried out before embarking on any infrastructure provision for which users will be expected to pay user charges. Application of similar studies in other Nigerian cities in the recommended manner will be of great benefits in improving infrastructure provision and economic development in the country. Transparency and stakeholder analysis and involvement will be helpful in attracting private investors. Toll road projects are fraught with a lot of risks and adequate care must be taken through comprehensive socioeconomic studies to minimize such which have been detailed in the literature. It is important that before a road is tolled, an alternative route should be provided unless with the express consent of the end users. 


\section{References}

Adedeji, B. (2009). The PPP (Public-Private Partnership) in the Megacity Development and The roles of the Built - Environment Professionals. Paper presented at the 2009 Lagos International Housing Conference organized by the Nigerian Institution of Estate Surveyors and Valuers (Lagos State), held in Lagos (21 ${ }^{\text {st }}$ May, 2009)

Annez, P.C., Huel, G. and Peterson G.E. (2008). Lessons for the Urban Century: Decentralized Infrastructure Finance in the World Bank. World Bank Washington D.C

Ardity, D, Akan, G.T. and Gurdamar, S. (1985). Cost overruns in public projects, International Journal of Project Management, 3: 218-225.

Bozzo, A. (1997) Guidelines For Rating Start - up Toll Roads. Fitch Research

Brandao, L.E.T Saraira, E.C.G. (2007), Valuing Government Guarantees in Toll Road projects National Bank for economic and social development Prio de Janeiro.

Brutton, M.J. (1975). Introduction to Transportation Planning. Hutchinson London

Bruzelui,. N., Flyvberg, B., Rothengatter, W. (2002). Big decisions, bug risks, Improving Accountability in Mega projects. Journal of Transport Mlicly (G; 143-153)

Buris. M.W. and Pendyala (2007). Discrete Choice Models of traveler Participation in differential time of day pricing programs. Journal of Transport Policy, No.9: 241-251.

Callan, S.J. and Thomas, J.M. (1996). Environmental Economics and Management. IRWIN: Chicago.

Chan, D.W.M. and Kumarashamy, M.M. (1997). A comparative study of cause of time overruns in Honking construction projects. International Journal of project management 15;5563.

Engel, E., Fischer, R. and Galetovic, A. (1997). A New Method for Auctioning Highways in Suzanne Smith: the Private Sector in Infrastructure: Strategy, Regulations and Risks, Pg. 109 - 112, World Bank, Washington D.C

Estache, A. and Carbajo, J. (1997). Designing Toll and Concession: Lessons from Argentina in Suzanne Smith: the Private Sector in Infrastructure: Strategy, Regulations and Risks, Pg. 113 - 116, World Bank, Washington D.C.

Fanning, S.F. (2005). Market Analysis for Real Estate. Appraisal Institute Chicago

Fay, M. and Morrison, M. (2007). Infrastructure in Latin America and the Caribbean. World Bank

Fisher, G. and Barber, S. (1996). Private Financing of Toll Roads, RMC Discussion Paper Series 117. The World Bank Washington

Flybyerg, B., Holm, M.K.S. and Buhl, S.L. (2004). What cause cost overrun in transport infrastructure projects. Transport Reviews, 2(1): 3-18.

Flybyery. B., Bruzelius, N., Rothengather, W. (2003). Mega Projects and Risks: An Anatomy of ambition Cambridge, Cambridge University Press.

Garrod, G. and Willis, K.G. (2001). Economic Valuation of the Environment, Edward Elgar

Hanley, N.C, Splash, C.L (1999) Cost Benefit Analysis and the Environment, M.A Edward Elgar Publishing. Northampton

Lake, M. and Ferreira, L. (2002). "Demand for Toll Roads: A Summary of Elasticities, Travel Time Values and Modeling Approaches" Transport 
Research Consortium, Queensland University of Technology, Brisbane

Lorenzen, C.C., Barrientos, M.E. and Babbar, S. (2000) Toll Road Concession: The Chilean Experience, The World Bank.

Mabogunje, A. (1993). Infrastructure: The case of modern urban development. The urban Age spring 1993: 3 - 6. World Bank, Washington D.C.

Mishra, S.K. (1998). Valuation of Environmental Goods and Services. An institutional assessment https://www.msu.edu/user/schmid/mish ra.htm

Morris, D.W.G. and Hough, G.H. (1987). The Anatomy of Major projects: A study of the Reality of project management (New York: Wiley)

Odeck, J. and Brathen, S. (2000). Toll Financing of Roads- The Norwegian Experiences. The World Bank Washington D.C.

Otegbulu, A.C. (2010). User Preference in Urban Infrastructure Provision Using the Contingent Valuation Model. PhD thesis at Enugu state University of Science and Technology, Enugu, Nigeria

Panayotou, T. (1998). The Role of the Private Sector in Sustainable Infrastructure development, Bridges to Sustainability Bulletin 101, UNDP.

Perman, R., Ma, Y., McGilray, J. and Common, M. (2003). Natural Resource and Environmental Economics, Pearson education Ltd, Edinburgh Gate

Runhaar, H. (2001), Efficient Pricing in Transport, the Gap between Theory and Practice, European Journal on Transport and Infrastructure Research, Pg. 29-44.

Snow, P. and Dinsen, B. (Eds) (1994). Beyond 2000: A source Book for Major Projects (Oxford; Major Projects Association)

United Nations Development Program (UNDP) (2006) Human Development Report (HDR) 2006. UNDP.

Whittington, D. (2002). The Challenges of Demand Assessment in Pro-Poor Infrastructure Projects. African Development Bank

Wibowo, A. (2004). Valuing guarantees in a BOOT infrastructure project journal of Engineering, Construction and Architectural Management 11 (6) 395403.

World Bank (1998). Decentralization Models and Issues in Latin America. World Bank Washington DC

World Bank (2000). Toll Roads and Concessions. The World Bank: Washington DC

World Bank (2006). Infrastructure at Crossroads: Lessons from 20 years of World Bank Experience. The World Bank: Washington D.C. 